\title{
Regulatory Justification of the Fundamental Concepts of Ergonomics in Wheeled Agricultural Machinery
}

\author{
Irina V. Egorova ${ }^{1 *}$, Nadezhda V. Petrenko ${ }^{1}$, Anna N. Tokareva ${ }^{1}$, \\ Sergey V. Panchenko ${ }^{1}$, Aleksandr E. Kalinin ${ }^{1}$
}

${ }^{1}$ Department of Technospheric Safety and Physics, Azov-Black Sea Engineering Institute of Don State Agrarian University, 21 Lenin Str., Zernograd, 347740, RUSSIAN FEDERATION

*Corresponding Author

DOI: https://doi.org/10.30880/ijie.2021.13.06.011

Received 19 August 2020; Accepted 5 February 2021; Available online 31 August 2021

\begin{abstract}
A single-seated man-machine system is formed when a person starts controlling a technical device or unit while undergoing production processes. Production tasks for man-machine system are developed by the senior system and contain output work parameters, which are determined by the properties of the human operator and the technical subsystem. The relevance of the article lies in the fact that it describes the ergonomics of wheeled agricultural machinery in regulatory standards. The purpose of the paper is to demonstrate the process of ensuring the working conditions of a single-seated man-machine system, the difficulties that arise upon performing tasks, including the content of regulatory acts, which are the technical foundation for the formation of the quality of operation of a single-seated man-machine system. Study results indicate external and internal restrictions that influence the efficient work of the human operator and are not provided for in regulatory standards, including ways to solve existing restrictions.
\end{abstract}

Keywords: Self-propelled agricultural machine, man-machine system, maintenance operations, labour safety, vibration parameters in tractors

\section{Introduction}

The operator of a self-propelled agricultural machine can be imagined as a single-seated man-machine system (MMS) as part of an agricultural enterprise. A single-seated man-machine system is a mobile technological unit consisting of two subsystems: a powerful engine with a set of operative parts, tools, unitized machines and a human operator. Figure 1 demonstrates the general structure of such an MMS [1]. The production assignment for a singleseated MMS is developed by the senior system and contains the necessary output parameters determined by the specific properties of the technical subsystem and the human operator. The external conditions in which the assignment is being performed essentially form an external environment that requires an independent study [2; 3]. We shall focus on restrictions. Firstly, the MMS operator performs all the tuning and adjustment operations, the parameters of which are determined by the environmental conditions. The technical converts parameters of outside environment into parameters of operating conditions of specific values. At performs all maintenance operations themself, using tools and materials. Thirdly, the operator themself performs the refuelling with propellants. Fourthly, the operator stops the operation of the MMS for dinner [4-6].

Upon task development, all the specified limitations must be taken into account. In general terms, all technical devices that together provide the set specific parameters of operating conditions to a human operator can be represented as a multidimensional producing operator that converts parameters of the outside environment into parameters of operating conditions of specific values [7]. At the same time, the producing operator must provide for their change over 
time so that they are adapted both to the age of the human operator and to the age of the technical tool. Figure 2 demonstrates a feedback conversion diagram [8-10].

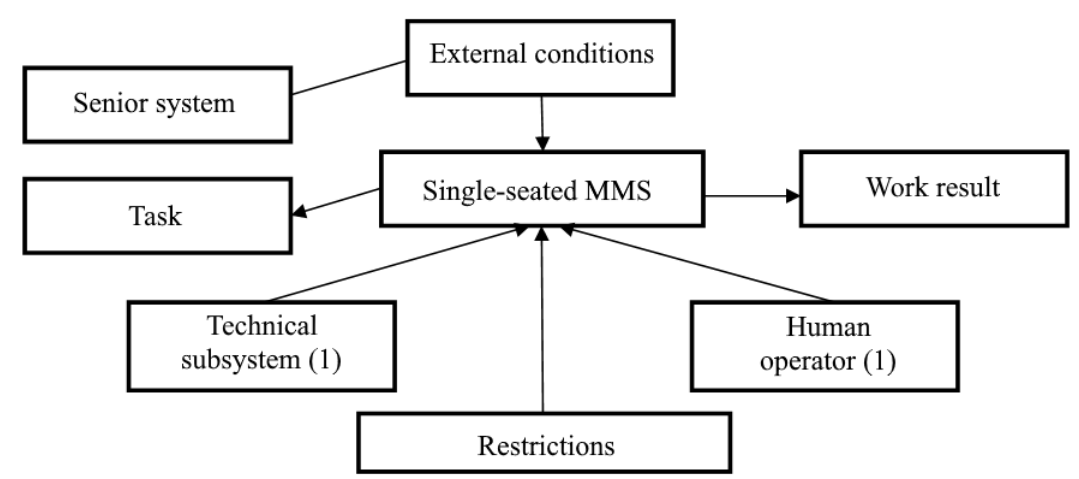

Fig. 1 - General structure of a single-seated man-machine system

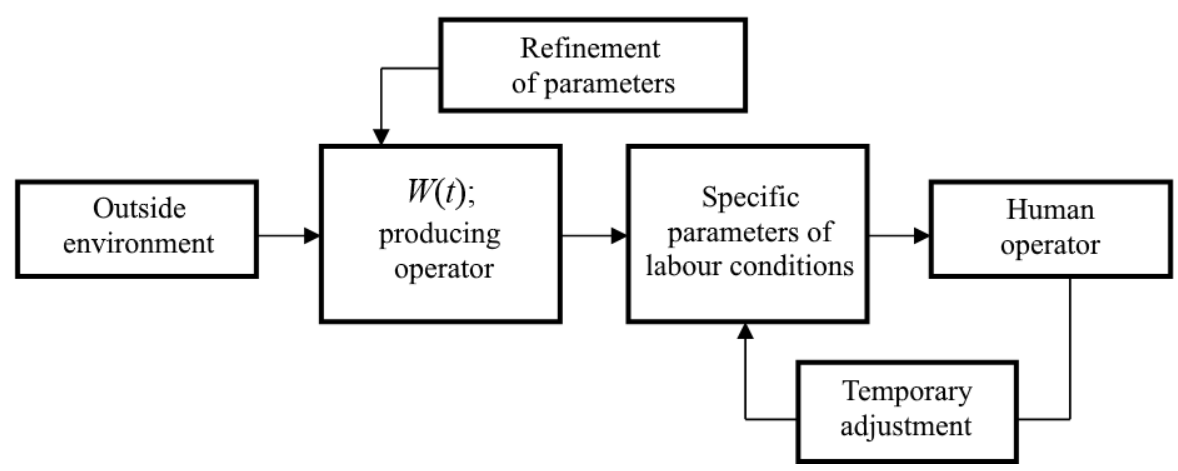

Fig. 2 - General scheme of the work of the producing operator

Using the model of the operator $\mathrm{W}(\mathrm{t})$, presented by the diagram in Figure 2, it is possible to demonstrate the complex process of providing working conditions for a single-seated MMS. With that, special attention is paid to two feedbacks, using which the parameters of the human operator correct the specific parameters of working conditions and refinement of the specifications of the producing operator on the basis of changes in the specific parameters of working conditions. Further, we shall consider those regulatory and technical fundamentals that form the actual parameters of the influence on the human operator and against which agricultural machinery is tested and evaluated, i.e., technical subsystem in the study of MMS [11; 12].

The purpose of the paper is to demonstrate the process of ensuring the working conditions of a single-seated manmachine system, the difficulties that arise upon performing tasks, including the content of regulatory acts, which are the technical foundation for the formation of the quality of operation of a single-seated man-machine system.

\section{Factors of the Formation of Regulatory and Technical Fundamentals of Labour in Agricultural Machinery}

These fundamentals are formed by the "Index of current regulatory documentation on agricultural machinery test methods, machinery and equipment for processing agricultural raw materials", which contains all applicable documents. Proceeding from this "Index", a table was compiled that includes the names of documents regulating the working conditions of the operator on technical means (Table 1). 
Table 1 - Regulatory and technical documentation for the regulation of labour conditions in agricultural machinery

\begin{tabular}{|c|c|}
\hline Document index & Document name \\
\hline GOST 12.2.019-2005 & Occupational safety standards system. Tractors and self-propelled agricultural machinery. \\
\hline GOST 12.2.002-91 & $\begin{array}{l}\text { Occupational safety standards system. Agricultural machinery. Safety Evaluation } \\
\text { Methods. }\end{array}$ \\
\hline GOST 12.2.002.4-91 & $\begin{array}{l}\text { Occupational safety standards system. Tractors and self-propelled agricultural } \\
\text { machinery. Methods for determining visibility from the operator's workplace. }\end{array}$ \\
\hline GOST 12.2.002.5-91 & $\begin{array}{l}\text { Occupational safety standards system. Tractors and self-propelled agricultural } \\
\text { machinery. Method for determining the characteristics of heating and microclimate } \\
\text { systems at the operator's workplace in the cold season. }\end{array}$ \\
\hline GOST 12.2.002.6-91 & $\begin{array}{l}\text { Occupational safety standards system. Tractors and self-propelled agricultural } \\
\text { machinery. Method for determining the tightness of cabs. }\end{array}$ \\
\hline OST 70.2.34-85 & $\begin{array}{l}\text { Agricultural machinery testing. Methods for measuring and analysing vibration of } \\
\text { mechanisms and components. }\end{array}$ \\
\hline RTM 70.23.026-80 & $\begin{array}{l}\text { Agricultural machinery testing. Comprehensive assessment and consideration of the } \\
\text { functional level of the operator. }\end{array}$ \\
\hline STP 13.064-81 & $\begin{array}{l}\text { The methodology for accelerated microclimate evaluation in the cabs of tractors } \\
\text { and self-propelled agricultural machinery by modelling conditions of outside } \\
\text { environment in a tropical chamber. }\end{array}$ \\
\hline STP $13.065-82$ & $\begin{array}{l}\text { The methodology for accelerated microclimate evaluation in the cabs of tractors } \\
\text { and self-propelled agricultural machinery by modelling conditions of outside } \\
\text { environment in an arctic chamber. }\end{array}$ \\
\hline STP 13.066-82 & $\begin{array}{l}\text { The methodology for accelerated microclimate evaluation in the cabs of tractors } \\
\text { and self-propelled agricultural machinery by modelling conditions of outside } \\
\text { environment in a dust chamber. }\end{array}$ \\
\hline STP $13.077-83$ & Occupational safety. Ensuring optimal working and resting conditions. \\
\hline STP 13.084-84 & $\begin{array}{l}\text { Agricultural machinery testing. Tractors and agricultural machinery. Methods for } \\
\text { assessing the starting qualities of engines in a cold chamber. }\end{array}$ \\
\hline GOST 12.2.002.1-91 & $\begin{array}{l}\text { Occupational safety standards system. Agricultural and forestry wheeled tractors. The } \\
\text { method of dynamic testing of protective structures. }\end{array}$ \\
\hline GOST 12.2.002.2-91 & $\begin{array}{l}\text { Occupational safety standards system. Agricultural and forestry wheeled tractors. The } \\
\text { method of static testing of protective structures. }\end{array}$ \\
\hline GOST 12.2.002.03-91 & $\begin{array}{l}\text { Occupational safety standards system. Agricultural and forestry vehicles. Determination of } \\
\text { braking performance. }\end{array}$ \\
\hline RD 10.2.33-89 & $\begin{array}{l}\text { Occupational safety standards system. Machines and equipment for livestock and feed } \\
\text { production. Safety and ergonomics evaluation methods. }\end{array}$ \\
\hline
\end{tabular}

Vibration parameters, as one of the main harmful production factors affecting the operator in the MMS system, are presented in Tables 2-4.

Table 2 - Vertical vibration parameters on tractor operator seat

\begin{tabular}{|c|c|c|c|c|c|}
\hline \multirow[t]{2}{*}{ Tractor class } & \multicolumn{5}{|c|}{$\begin{array}{l}\text { Root mean square vertical accelerations, } \mathrm{m} / \mathrm{s}^{2}, \text { in octave bands with a } \\
\text { geometric mean frequency, } \mathrm{Hz}\end{array}$} \\
\hline & 2 & 4 & 8 & 16 & 31.5 \\
\hline 0.6 & 1.15 & 0.8 & 0.60 & 1.14 & - \\
\hline $0.9-1.4$ & 1.30 & 0.60 & 0.50 & 0.40 & - \\
\hline 2 & 1.20 & 0.60 & 0.50 & 0.40 & - \\
\hline 3 (wheeled) & 1.30 & 0.45 & 0.35 & 0.40 & - \\
\hline 3 and higher (caterpillar) & 0.55 & 0.60 & 0.90 & 1.00 & 1.90 \\
\hline 5 and higher (wheeled) & 1.30 & 0.40 & 0.25 & 0.25 & - \\
\hline
\end{tabular}


Table 3 - Horizontal vibration parameters on the seat and (or) the operator's platform of tractors and machines

\begin{tabular}{|c|c|c|c|c|c|c|c|}
\hline \multirow[t]{2}{*}{ Parameter } & \multicolumn{7}{|c|}{$\begin{array}{c}\text { Parameter values in an octave band with a geometric mean } \\
\text { frequency, } \mathrm{Hz}\end{array}$} \\
\hline & 1 & 2 & 4 & 8 & 16 & 31.5 & 63 \\
\hline Root mean square acceleration value, $\mathrm{m} / \mathrm{s}^{2}$ & 0.632 & 0.846 & 1.60 & 3.21 & 6.39 & 12.76 & 25.52 \\
\hline
\end{tabular}

Table 4 - Vibration parameters on the controls of tractors and machines

\begin{tabular}{lccccc}
\hline \multirow{2}{*}{ Tractor class } & \multicolumn{5}{c}{ Parameter values in an octave band with a geometric mean } \\
& \multicolumn{3}{c}{ frequency, Hz } \\
& $\mathbf{1 6}$ & $\mathbf{3 1 . 5}$ & $\mathbf{6 3}$ & $\mathbf{1 2 5}$ & $\mathbf{2 5 0}$ \\
\hline Root mean square acceleration value, $\mathrm{m} / \mathrm{s}^{2}$ & $4.0 \cdot 10^{-2}$ & $2.8 \cdot 10^{-2}$ & $2.0 \cdot 10^{-2}$ & $1.4 \cdot 10^{-2}$ & $1.0 \cdot 10^{-2}$ \\
Speed level, $\mathrm{dB}$ & 118 & 115 & 112 & 109 & 106 \\
\hline
\end{tabular}

GOST 12.2.002.5-91 regulates the method of determining the characteristics of the heating and microclimate system at the operator's workplace in the cold season and provides for the measurement of ambient temperature, regulating the measurement of the parameter for an engine with exhaust and forced draft fans; temperature measurement of the engine, heater and coolant flow. With that, a geometric diagram of the measuring points is given, bound to the seat index point.

GOST 12.2.002.6-91 regulates the method for determining the tightness of the operator's cab, which is established by the difference between the static air pressure inside and outside the cab, measured in millimeters of water column or in pascals. The visibility parameters are regulated by GOST 12.2.019-2005 on the basis that the design of tractors and self-propelled agricultural machines should provide visibility of the following objects from the operator's workplace in the working position "when seated": space in the field of vision; visor (structural components) and motion cues (for example, a furrow, wheel or caterpillar track, etc.); areas for unloading a technological product into a vehicle; structural elements of tractors and self-propelled machines serving for hitching and coupling with unitized machines and tools. The location of the reference points of the visibility parameters $\mathrm{K}$ and the visibility lines are presented in Figure 3.
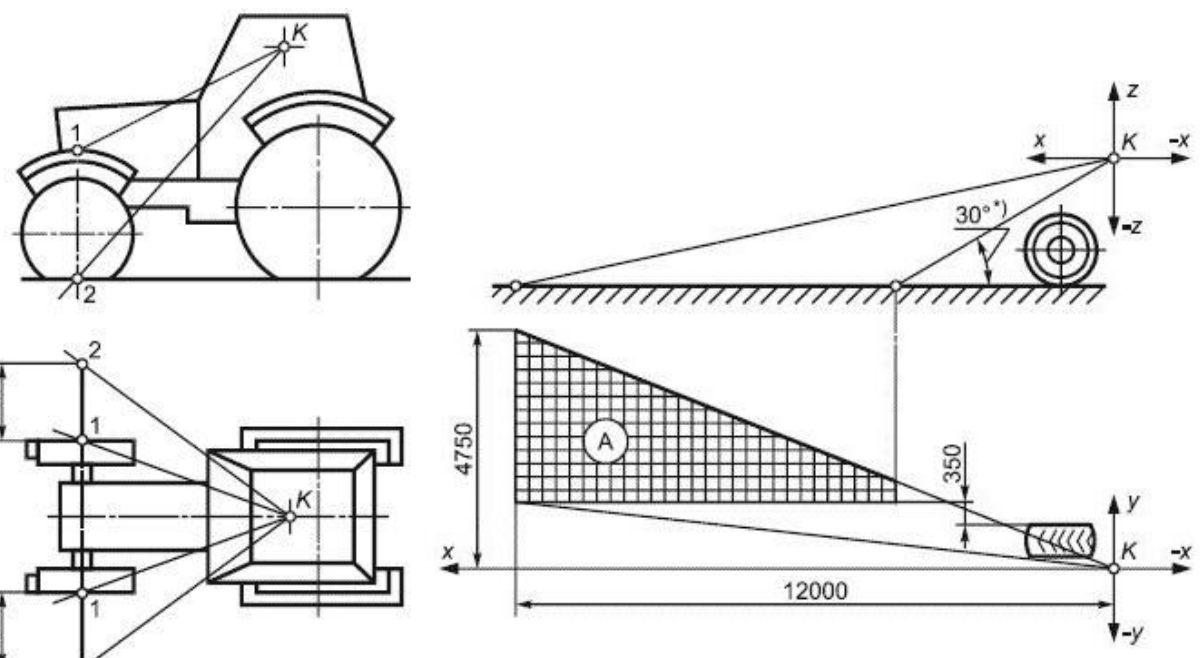

Fig. 3 - Visibility limits on a universal tractor in accordance with GOST 12.2.019-2005

\section{Regulated Structural Parameters of Cabs for Tractors of Different Classes}

Caterpillar tractors of drawbar categories 3-5 must provide for an overview of the front of the caterpillar (point 1) and the A1 section in front of the caterpillar (Figure 4) [13; 14]. For a self-propelled agricultural machine, the angles and lines of sight are presented in Figure 5. GOST provides for front and rear visibility zones, while allowing no more than two invisible sections for agricultural wheeled and tracked tractors within each of sectors 1-2 and 1-3 (Figure 6). Width in the invisible areas in sector 1 should not exceed $700 \mathrm{~mm}$, and in sectors 2 and $3-1200 \mathrm{~mm}$. With that, for machines with a symmetrical cab layout, the visibility of points P1, P2, P3, P4 must be ensured (Figure 5) [15; 16]. 


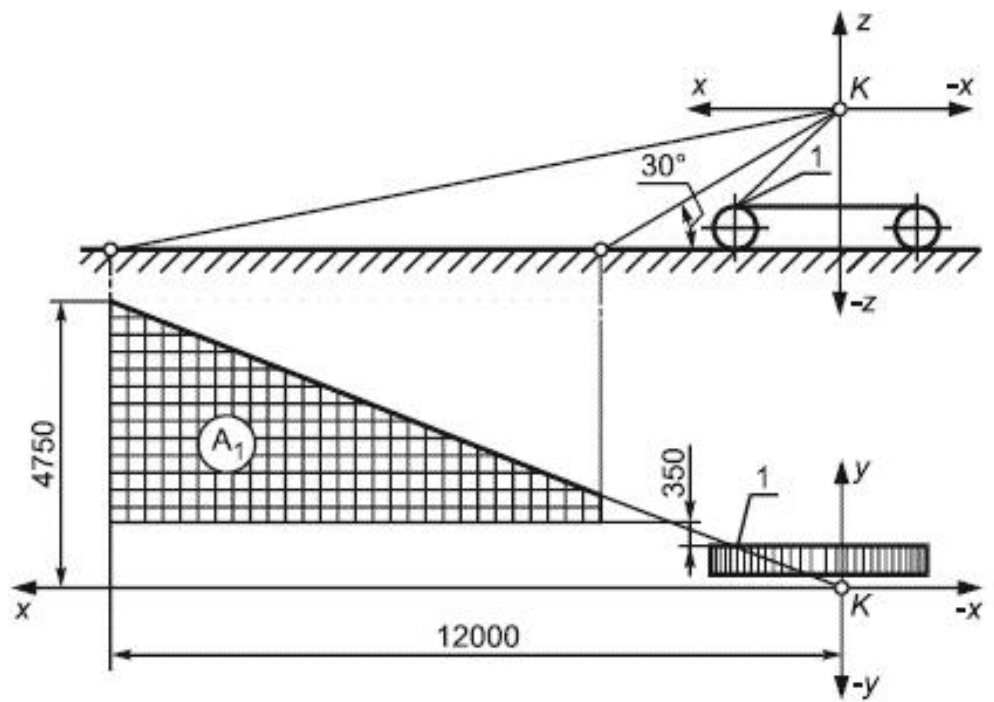

Fig. 4 - Visibility limits on caterpillar tractors of categories 3-5 in accordance with GOST 12.2.019-2005
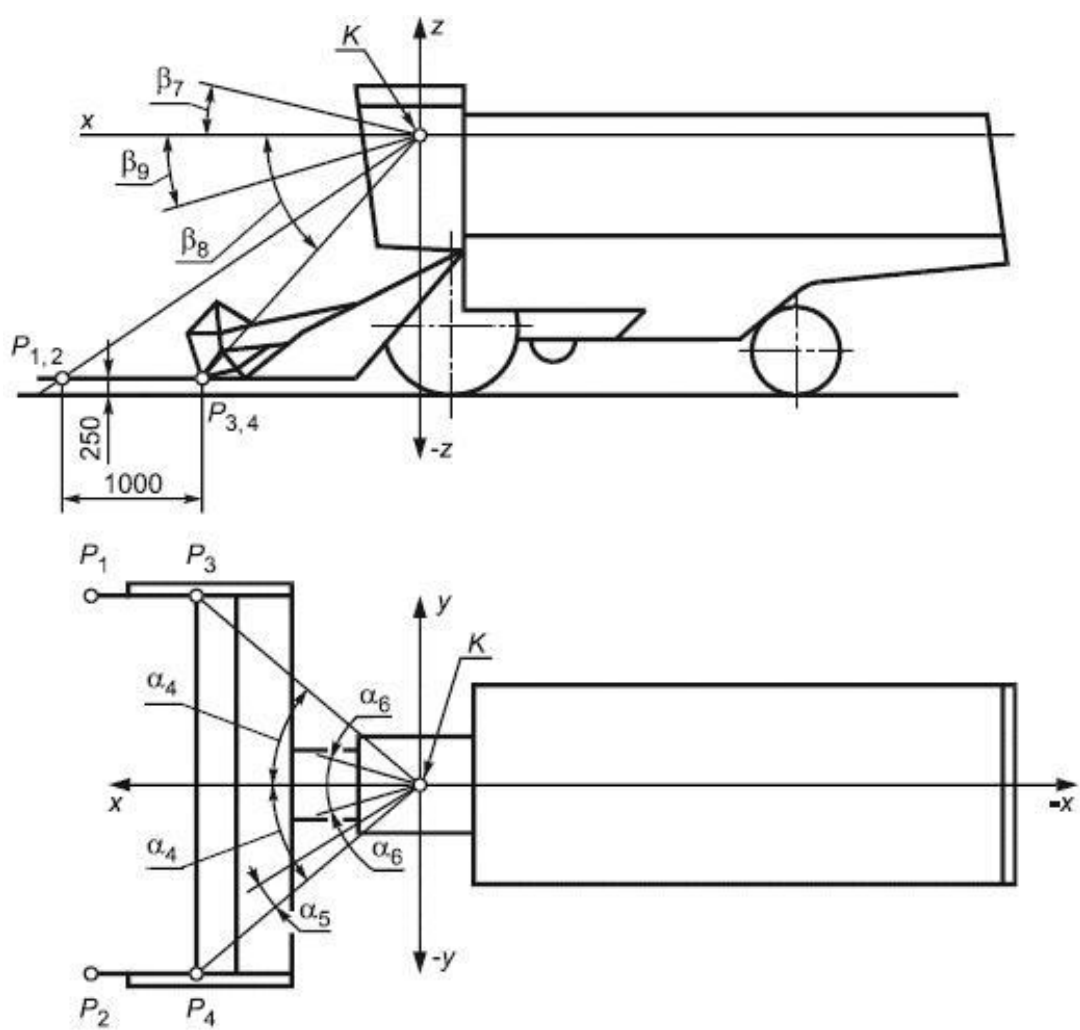

Fig. 5 - Lines, angles and points of vision on a self-propelled agricultural machine in accordance with GOST 12.2.019-2005 


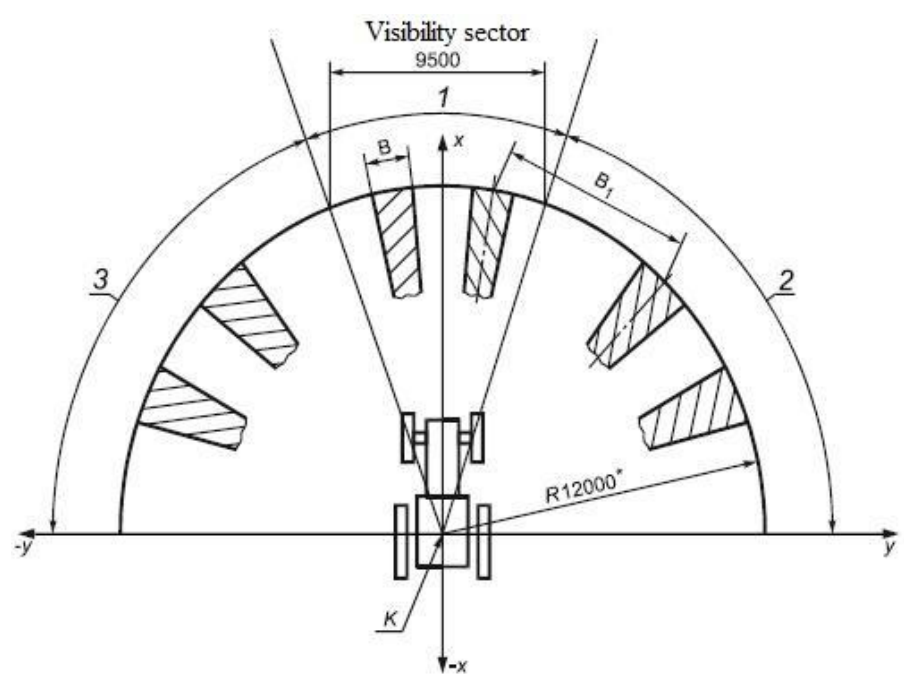

Fig. 6 - A semicircle of the front visibility zone from the tractor cabin in accordance with GOST 12.2.0192005

GOST 12.2.002.4-91 provides for a method of determining visibility from the operator's workplace. They are given measurement methods, in particular, the semicircles of the front and rear visibility zones (Figure 6).

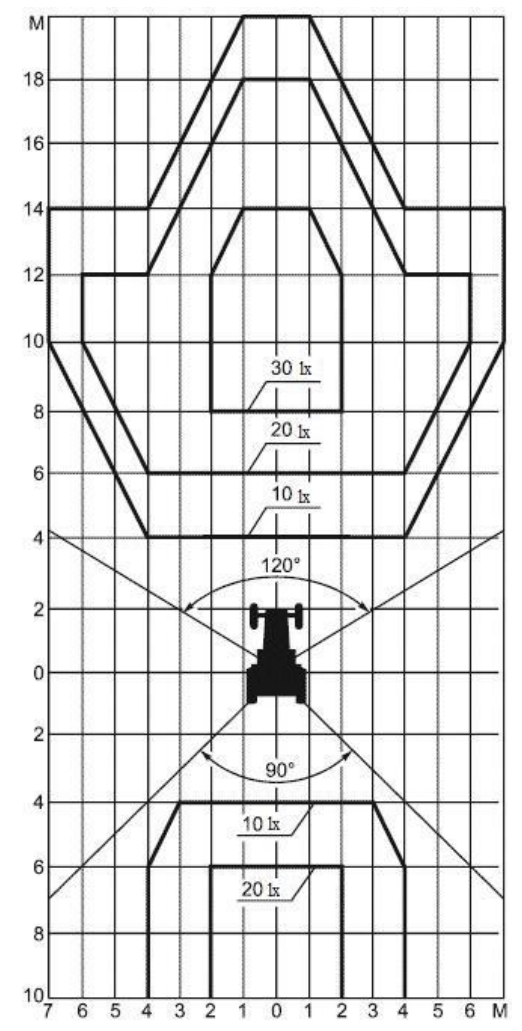

Fig. 7 - Recommended illumination of working areas in accordance with GOST 12.2.019-2005

GOST 12.2.019-2005 regulates the standardization of illumination parameters. Tractors and agricultural machinery must have a transport and working system of external lighting, which are switched on independently. The working system should provide illumination of the field during the technological operation, and transport system - the illumination of roads. Recommended illumination provided jointly by the working and transport lighting systems for tractors is presented in Figure 7.

GOST provides for illumination of working areas in relation to various areas of the working field. GOST contains general safety requirements when using mounted, semi-mounted, trailed, semi-trailed machines and tools, unitizes with 
various energy means, provides acceptable values of resistance forces to the movement of controls. Their main values are presented in Table 5 [17-20].

Table 5 - Permissible values of resistance forces of controls

\begin{tabular}{lc}
\hline Groups of controls & Permissible values of strength, N \\
\hline Often used: & 60 \\
- with manual operation & 200 \\
- with foot control & \\
Rarely used (no more than 5 times per shift): & 200 \\
- with manual operation & 300 \\
- with foot control & 400 \\
Parking brake lever & \\
\hline
\end{tabular}

\section{Conclusions}

The authors believe that the results obtained are fully consistent with the task. This was made possible by carrying out measurements and assessing all of the above factors in real conditions. From the research it can be concluded that the operator works in difficult conditions for most of the period of the "life" of a technical tool. With that, no measurements of the parameters of the production environment are provided for during the entire service life of technical equipment.

Proceeding from the above, we shall note that, in our opinion, it is necessary to develop appropriate regulatory materials containing requirements for the parameters of working conditions throughout the life of the unit with the exact terms for monitoring these parameters.

\section{References}

[1] Gorshkov, Yu. G., Starunova, I. N., Kalugin, A. A., \& Belousov, M. A. (2014). Investigation of the influence of the slope angle on the imbalance in the loading of the sides of the wheeled vehicle and the change in the direction of the centre of gravity vector. Science Review, 1, 28-32

[2] Roopaei, M., Rad, P., \& Choo, K. R. (2017). Cloud of things in smart agriculture: Intelligent irrigation monitoring by thermal imaging. IEEE Cloud Computing, 4(1), 10-15

[3] Ren, R. Q. (2020). Intelligent control technology of agricultural greenhouse operation robot based on fuzzy pid path tracking algorithm. INMATEH - Agricultural Engineering, 62(3), 181-190

[4] Shabanov, N. I., Lipkovich, I. E., Petrenko, N. V., Piatikopov, S. M., Pikalov, A. V., Egorova, I. V., \& Gaidai A. S. (2018). Ergonomics and psychophysiological fundamentals of labour safety in the agro-engineering field. Zernograd: Azov-Black Sea Engineering Institute Federal State Budgetary Educational Institution of Higher Education of the Don State Agrarian University

[5] Benos, L., Tsaopoulos, D., \& Bochtis, D. (2020). A review on ergonomics in agriculture. part II: Mechanized operations. Applied Sciences, 10(10), article number 3484

[6] Sanzhapov, R. R., \& Balakina. E. V. (2011). Analysis of the influence of the base on traffic stability. Tractors and Agricultural Machinery, 8, 21-24

[7] Hou, J., Chen, Y., Li, Y., Wang, W., \& Li, G. (2020). Development of quantitatively-laying and self-propelled green onion combine harvesters. Transactions of the Chinese Society of Agricultural Engineering, 36(7), $22-33$.

[8] Lipkovich, I. E., \& Petrenko, N. V. (2011). The impact of operator motivation on the performance of manmachine systems. Tractors and Agricultural machinery, 10, 46-50

[9] Ehlers, S. G., \& Field, W. E. (2019). Accessing and operating agricultural machinery: Advancements in assistive technology for users with impaired mobility. Assistive Technology, 31(5), 251-258

[10] Rotenberg, R. V. (2008). The basics of reliability of the driver-car-road-environment system. Moscow: Mashynostroenie

[11] Venda, V. F. (2009). Ergonomics, problems of adaptation of working conditions to a person. Moscow: Mir

[12] Fitts, P. M. (2010). Human engineering for an effective air navigation and traffic control system. Washington: National Research Council

[13] Kanniga Devi, R., \& Muthukannan, M. (2020). An internet of things-based economical agricultural integrated system for farmers: A review, International Conference on Intelligent Computing and Control Systems, ICICCS 2020. Madurai, India, article number 161336

[14] Caplan, R. D., Cobb, S., French Jr, J. R. P., Harrison, R. V., \& Pinneau Jr, S. R. (2010). Job demands and worker health. Washington: U.S. Government Printing Office

[15] Wang, F., Sun, G., \& Shang, S. (2019). Development of 4CL-1 self-propelled combine harvester for green onion. Transactions of the Chinese Society of Agricultural Engineering, 35(24), 39-47

[16] Kotarbiński, T. (1958). Traktat o dobrej robocie. Wrocław-Warszawa: Zakład Narodowy im. Ossolińskich. 
[17] Cailliet, R. (2011). Shoulder pain. Philadelphia: F.A. Davis Company

[18] Wang, H., \& Xu, B. (2020). Research on modeling design of modern agricultural machinery based on soft system methodology. AHFE International Conference on Interdisciplinary Practice in Industrial Design, 2019. Washington, United States, article number 227219

[19] Yu, N., Wang, Q., \& Cao, S. (2020). Road recognition technology of agricultural navigation robot based on road edge movement obstacle detection algorithm. INMATEH - Agricultural Engineering, 61(2), 281-292

[20] Xiao, Z., XI, Fang, Z., \& Shuaifei, S. (2018). Design of remote monitoring system of irrigation based on GSM and ZigBee technology, 4th International Conference on Advanced Engineering and Technology. Incheon, South Korea, article number 135313 